\title{
Evaluasi Kualitas Website Digital Library UMM Menggunakan Metode Webqual 4.0 dan Importance Performance Analysis
}

\author{
Muhammad Reza Ashari ${ }^{*}{ }^{*}$, Dharma Surya Pradana ${ }^{2}$, Evi Dwi Wahyuni ${ }^{3}$ \\ 1,2,3 Teknik Informatika/Universitas Muhammadiyah Malang \\ M.rezaashari@gmail.com ${ }^{* 1}$, dharmasuryapradana@gmail.com², evi.d.wahyuni@gmail.com ${ }^{3}$
}

\begin{abstract}
Abstrak
Digital Library adalah perpustakaan yang mengelola semua atau sebagian yang subtansi dari koleksi-koleksinya dalam bentuk komputerisasi sebagai bentuk alternatif, suplemen atau pelengkap terhadap cetakan konvensional dalam bentuk mikro material yang saat ini didominasi koleksi perpustakaan. Namun, dari sejak awal hingga saat ini belum pernah dilakukan evaluasi terhadap Digital Library yang dikaji dari sisi kualitasnya. Evaluasi dilakukan untuk menjawab permasalahan bagaimana pendapat pengguna tentang kualitas Digital Library yang telah diimplementasikan Universitas Muhammdiyah Malang. Berdasarkan Hasil penelitian ditemukan bahwa pada variabel usability dengan nilai 0,67 , information quality 0,86 , service interaction 0,71 dan untuk rata-rata dari keseluruhan variabel 0,74 . Dari hasil analisis kesenjangan ditemukan bahwa seluruh variabel bernilai positif atau Qi GAP > 0 yang artinya kinerja sudah sesuai yang diharapkan oleh pengguna. kesimpulan yang didapatkan ada 15 atribut yang masuk kedalam kuadran 1 dan 3 . Saran yang diberikan berupa rekomendasi mockup untuk meningkatkan kualitas pada kuadran 1 dan 3 IPA. Kesimpulan dari penelitian bahwa kualitas dari website Digital Library masih kurang karena masih banyak atribut yang perlu ditingkatkan kualitasnya.
\end{abstract}

Kata Kunci: Digital Library, Webqual 4.0, Importace Performance Analysis (IPA), Analisis Kesesuaian, Analisis Kesenjangan, Kuadran IPA.

Digital Library is a library that manages all or part of the substance of its collections in the form of computerization as an alternative form, supplement or complement to conventional molds in the form of micro-material which is currently dominated by library collections. However, from the beginning until now there has never been an evaluation of the Digital Library that was reviewed in terms of quality. Evaluation is do to answer the problem of how the user thinks about the quality of the Digital Library that has been implemented by Malang Muhammadiyah University. Based on the results of the study found that the usability variable with a value of 0.67 , information quality 0.86 , service interaction 0.71 and for the average of the overall variable 0.74 . From the results of the gap analysis it was found that all variables were positive or Qi GAP >0 which meant that the performance was as expected by the user. the conclusions obtained are 15 attributes that enter into quadrants 1 and 3 . The advice given is a mockup recommendation to improve the quality of quadrants 1 and 3 IPA. The conclusion from the study that the quality of the Digital Library website is still lacking because there are still many attributes that need to be improved in quality.

Keywords: Digital Library, Webqual 4.0, Importace Performance Analysis (IPA), Conformity Analysis, Gap Analysis, Quadrants IPA

\section{Pendahuluan}

Teknologi saat ini telah mengalami perkembangan yang sangat pesat. Peran sistem informasi didalam dunia akademik menjadi bagian penting bagi kelangsungan suatu lembaga pendidikan. Dengan dukungan sistem informasi yang baik, sebuah lembaga pendidikan akan emiliki keunggulan kompetitif sehingga berdaya saing tinggi [1]. Seperti yang tertulis dalam Undang-Undang Perpustakaan No.43 tahun 2007 pada bab V pasal 14 setiap perpustakaan mengembangkan perpustakaan sesuai dengan kemajuan teknologi dan komunikasi [2].

Saat ini telah banyak lembaga pendidikan yang mulai menerapkan sistem informasi untuk meningkatkan layanan kepada pemustaka, salah satunya Universitas Muhammadiyah Malang yang telah mengimplementasikan Digital Library. Digital Library adalah perpustakaan yang mengelola semua atau sebagian yang subtansi dari koleksi-koleksinya dalam bentuk 
komputerisasi sebagai bentuk alternatif, suplemen atau pelengkap terhadap cetakan konvensional dalam bentuk mikro material yang saat ini didominasi koleksi perpustakaan [3].

Digital Library diharapkan mempermudah mahasiswa mencari buku dan hasil penelitian. Namun, dari sejak awal hingga saat ini belum pernah dilakukan evaluasi terhadap Digital Library yang dikaji dari sisi kualitasnya. Amanda dwi P. Galang dkk mengutip B.kitchenham and J. Walker untuk mendefinisikan sebuah kualitas, telah banyak definisi yang telah dikenalkan. International Standards Organisation (ISO) mendefinisikan kualitas sebagai "the totality of features and characteristics of a product or service that bear on its ability to satisfy specified or implied needs" yang berarti totalitas dari fitur dan karateristik dari produk atau layanan yang bergantung dari kemampuan untuk memuaskan kebutuhan pengguna [4].

Evaluasi dilakukan untuk menjawab permasalahan bagaimana pendapat pengguna tentang kualitas Digital Library yang telah diimplementasikan Universitas Muhammdiyah Malang. Evaluasi adalah pemberian nilai terhadap kualitas tertentu dan evaluasi juga dapat dipandang sebagai merencanakan, memperoleh, dan menyediakan informasi yang sangat diperlukan untuk membuat alternatif-alternatif keputusan [5].

Pada penelitian ini yang akan dijadikan responden sebatas dari fakultas FKIP karena berdasarkan data pengguna dari digital library menunjukkan bahwa dari total keseluruhan pengguna yaitu 2689 orang dengan pengunjung terbanyak dari fakultas FKIP dengan total 779 orang. Alasan digenarilisasi ke fakultas FKIP diharapkan orang pada populasi tersebut lebih bisa menggambarkan secara refresentatif terhadap kualitas website Digital Library Universitas Muhammadiyah Malang.

Saat ini terdapat beberapa metode yang dapat mengukur kualitas layanan website seperti E-Govqual, Servqualdan Webqual. Pengukuran kualitas menggunakan metode E-Govqualuntuk mengukur kualitas layanan dibidang E-Government [6]. Pengukuraan kualitas menggunakan metode Servqual untuk mengukur kualitas layanan dibidang jasa [7]. Pengukuran kualitas menggunakan metode Webqual untuk mengukur kualitas dibidang pekerjaan, situs pendidikan, perpustakaan, dll [8].

Metode yang digunakan dalam penelitian ini yaitu metode Webqual untuk mengukur kualitas layanan di Digital Library Universitas Muhammadiyah Malang. Webqual berdasarkan pada konsep Quality Fuction Deployment (QFD) yaitu suatu proses yang berdasarkan pada "voice of costumer" dalam pengembangan dan implementasi suatu produk atau jasa. Dari konsep QFD tersebut, Webqual disusun berdasarkan pada persepsi pengguna akhir (end user) terhadap suatu website [9]. Selanjutnya untuk mengetahui tingkat harapan dan kinerja dari evaluasi tersebut akan digunakan metode IPA (Importance Performance Analysis).

Metode IPA (Importance Performance Analysis) digunakan untuk mengidentifikasi faktor apa saja yang harus ditingkatkan kinerjanya untuk memenuhi kepuasaan pengguna pada sebuah organisasi atau perusahaan. Penggunaan metode IPA sendiri terus berkembang seiring berkembangan zaman. Awalnya metode ini hanya digunakan dalam bidang pemasaran, namun sekarang metode ini telah digunakan diberbagai bidang seperti instansi pemerintahan, sekolah hingga pariwisata [10]. Penilaian atribut menggunakan metode ini dilakukan dengan analisis tingkat kesesuaian, analisis kesenjangan dan analisis kuadran.

Dengan dipaparkannya permasalah diatas membuat penulis tertarik untuk melakukan evaluasi kualitas di Digital Library Universitas muhammdiyah malang. Metode yang digunakan untuk melakukan evaluasi yaitu Webqual 4.0 dan analisis IPA yang akan mendapatkan informasi atribut-atribut yang perlu mendapatkan perbaikan untuk meningkatkan kualitas.

\section{Metode Penelitian}

\subsection{Metodologi Penelitian}

Penelitian ini menggunakan jenis metode kuantitatif deskriptif. Penelitian kuantitatif dapat diartikan sebagai metode penelitian yang berlandaskan pada filsafat positivisme, digunakan untuk meneliti pada populasi atau sampel tertentu, pengumpulan data menggunakan instrumen penelitian, analisis data bersifat kuantitatif/statistik, dengan tujuan untuk menguji hipotesis yang telah ditetapkan [11]. Penelitian kuantitatif deskriptif merupakan penelitian yang bertujuan menjelaskan fenomena yang ada dengan menggunakan angka-angka untuk karakteristik individu atau kelompok [12], seperti yang ditujukkan pada Gambar 1. 


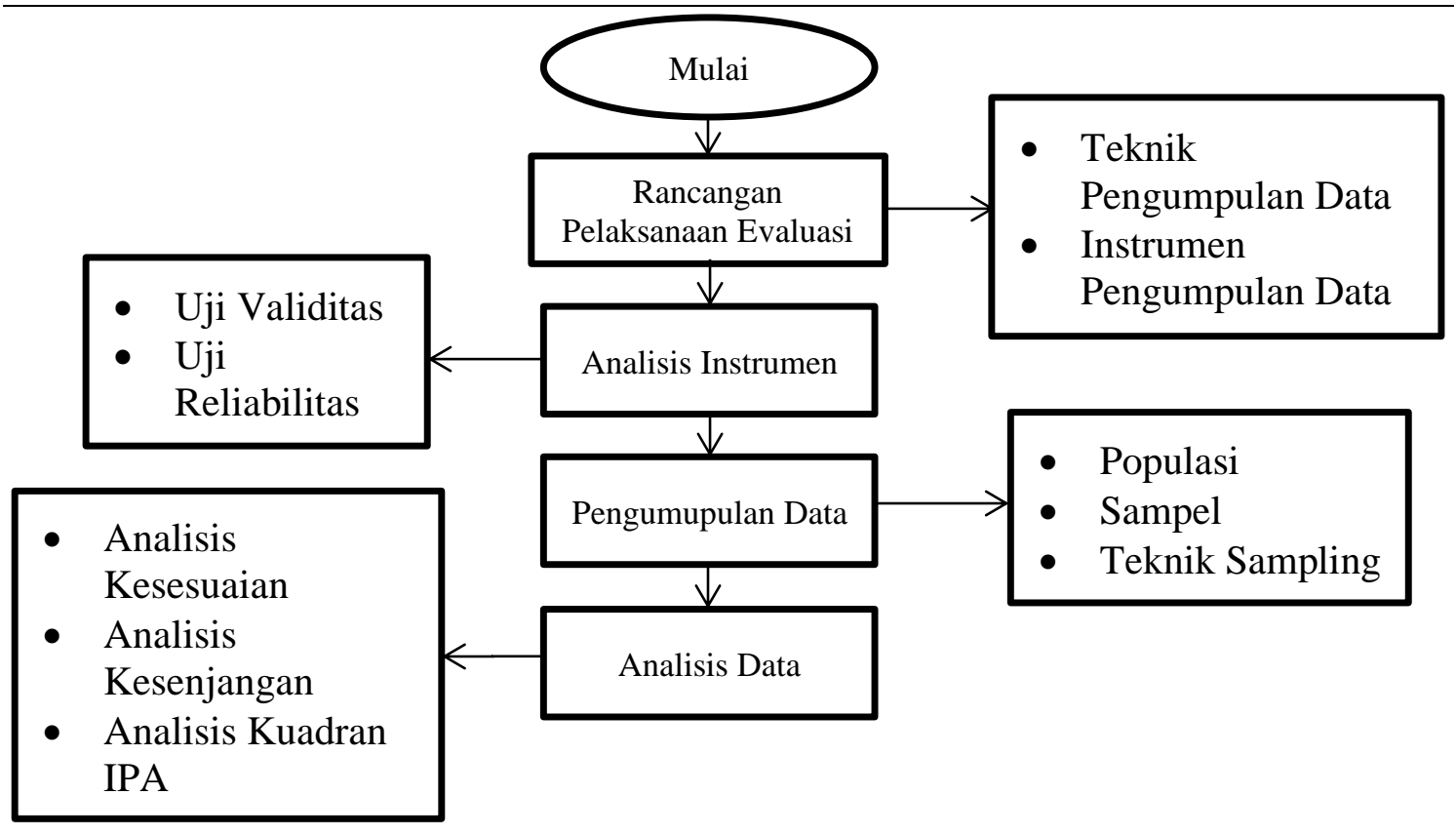

Gambar 1. Alur Metodologi Penelitian

\subsection{Rancangan Pelaksanaan Evaluasi}

Pada tahap rancangan pelaksanaan evaluasi akan dilakukan menjadi dua tahapan yaitu teknik pengumpulan data dan instrumen pengumpulan data.

\subsubsection{Teknik Pengumpulan Data}

Teknik pengumpulan data merupakan langkah yang paling utama dalam proses penelitian, karena tujuan utama dari penelitian adalah mendapatkan data. Selanjutnya bila dilihat dari segi cara atau teknik pengumpulan data dapat dilakukan dengan interview (wawancara), kuisioner (angket), observasi (pengamatan) [11].

\subsubsection{Instrumen Pengumpulan Data}

Instrumen penelitian ini menggunakan kuisioner yang di adobsi dari kuisioner WebQual 4.0 dengan 22 butir pertanyaan. Pada penelitian ini, peneliti menggunakan skala sikap model Likert. Skala Likert digunakan untuk mengukur sikap, pendapat dan persepsi seseorang atau sekelompok orang tentang fenomena sosial. Dengan Skala Likert, maka variabel yang akan diukur dijabarkan menjadi indikator variabel kemudian indikator tersebut dijadikan sebagai titik tolak untuk menyusun item-item instrumen yang dapat berupa pertanyaan atau pernyataan [11].

\subsection{Analisis Instrumen}

Pada tahap analisis instrumen akan dilakukan beberapa tahapan yaitu Uji Validitas dan Uji Reliabilitas. Pengujian dilakukan menggunakan software SPSS 2.5 for Windows.

\subsubsection{Uji Validitas}

Validitas berasal dari kata validity yang mempunyai arti sejauh mana akurasi alat tes atau skala dalam menjalankan fungsi pengukurannya. Pengukuran dikatakan mempunyai validitas yang tinggi apabila menghasilkan data secara akurat memberikan gambaran mengenai variabel yang diukur seperti dikehendaki oleh tujuan pengukuran tersebut[13]. Rumus yang digunakan untuk menguji validitas instrumen dalam penelitian ini adalah korelasi Product Moment.

\subsubsection{Uji Reliabilitas}

Reliabilitas merupakan penerjemahan dari kata reliability. Suatu alat ukur yang mampu menghasilkan data yang memiliki tingkat reliabilitas tinggi disebut sebagai pengukuran yang reliabel (reliable). Walaupun istilah reliabilitas mempunyai berbagai nama lain seperti konsisten, keterandalan, keterpercayaan, kestabilan, keajengan, dan sebagainya, namun gagasan pokok 
yang terkandung dalam konsep reliabilitas adalah sejauh mana hasil suatu proses pengukuran dapat di percaya[13]. Uji reliabilitas dalam penelitian ini dilakukan dengan rumus Cronbach Alpha.

\subsection{Pengumpulan Data}

Pada tahap pengumpulan data akan dibagi menjadi tiga tahapan yaitu menentukan populasi, sampel dan teknik sampel.

\subsubsection{Populasi}

Populasi adalah wilayah generalisasi yang berdiri atas obyek/subyek yang mempunyai kualitas dan karakteristik tertentu yang di tetapkan oleh peneliti untuk dipelajari dan kemudian ditarik kesimpulannya[11]. Pada penelitian ini yang menjadi populasi adalah pengguna website Digital Library Universitas Muhammadiyah Malang. Diketahui bahwa jumlah pengguna pada tahun 2017 dari fakultas FKIP sebanyak 779 orang, selanjutnya dari total keseluruhan populasi nantinya sebagian akan dijadikan sampel dalam penelitian ini.

\subsubsection{Sampel}

Sampel adalah bagian dari jumlah dan karakteristik yang dimiliki oleh pupolasi tersebut. Bila populasi besar, dan peneliti tidak mungkin mempelajari semua yang ada pada populasi, misal karena keterbatasan dana, tenaga dan waktu, maka peneliti dapat menggunakan sampel yang diambil dari populasi tersebut. Dalam penelitian ini peneliti menggunakan rumus Slovin sebagai teknik sampling seperti pada Persamaan 1 berikut.

$$
n=\frac{N}{1+N e^{2}}
$$

Untuk nilai N peneliti menetapkan 779 dari total populasi dan nilai $e^{2}$ adalah 0,01 sehingga jumlah responden sebagai sampel dalam penelitian ini sebanyak 88,62 dan di bulatkan menjadi 89 responden.

\subsubsection{Teknik Sampling}

Dalam penelitian ini menggunakan teknik sampling non probability sampling dengan pendekatan purposive sampling. Purposive sampling adalah teknik penentuan sampel dengan pertimbangan tertentu. Dalam hal ini yang dijadikan pertimbangan harus dari universitas muhammadiyah malang dan dari fakultas FKIP yang pernah menggunakan website Digital Library universitas muhammadiyah malang.

\subsection{Analisis Data}

Pada tahap analisis data akan dilakukan tiga tahapan yaitu analisis kesesuaian, analisis kesenjangan dan analisis kuadran.

\subsubsection{Analisis Kesesuaian}

Analisis kesesuaian merupakan hasil dari perbandingan antara skor kinerja pelaksanaan (performance) dengan skor kepentingan (importance) yang kemudian akan dimuat dalam tabel presentase skor kinerja dan skor kepentingan. Adapun rumusnya pada Persamaan 2 berikut.

$$
T k i=\frac{x i}{y i} x 100 \%
$$

Keterangan:

Tki : tingkat kesesuaian

$X i$ : skor kinerja (performance)

Yi : skor kepentingan (importance)

\subsubsection{Analisis Kesenjangan}

Analisis kesenjangan (gap) dilakukan untuk melihat sejauh mana tingkat kualitas dari website Digital Library Universitas Muhammadiyah Malang yang ditinjau dari nilai kesenjangan

REPOSITOR, Vol. 2, No. 3, Maret 2020: 351-362 
antara kualitas yang dirasakan (aktual) dan kualitas yang diinginkan atau harapan (ideal). Kualitas aktual ditunjukan melalui penilaian responden terhadap kinerja (performance) sedangkan unntuk kualitas ideal ditunjukan berdasarkan penilaian responden terhadap tingkat kepentingan (importance). Persamaan 3 menampilkan, proses untuk menentukan nilai kesenjangan (gap) dapat dihitung dari selisih nilai antar kualitas website aktual (performance) dan kualitas website ideal (importance) [14].

$$
Q i(G a p)=\operatorname{Perf}(i)-\operatorname{Imp}(i)
$$

Keterangan:

Qi(gap) : nilai kesenjangan

Perf(i) : nilai rata-rata kinerja

Imp(i) : nilai rata-rata kepentingan

\subsubsection{Analisis Kuadran}

Tahap pertama untuk analisi kuadran adalah menggunakan diagram kertesius dengan perpotongan sumbu $X$ dan $Y$ sehingga terbentuk 4 kuadran. Sumbu $X$ mewakili kinerja (performance) dan sumbu $Y$ mewakili kepentingan (importance). Langkah pertama adalah menghitung rata-rata penilaian kinerja dan kepentingan untuk setiap atribut dengan Persamaan 4.

$$
\begin{gathered}
\overline{X i}=\frac{\sum_{i=1}^{k} X i}{n} \\
\bar{Y} i=\frac{\sum_{i=1}^{k} Y i}{n}
\end{gathered}
$$

Langkah kedua adalah menghitung rata-rata tingkat kinerja dan kepentingan untuk keseluruhan atribut dengan Persamaan 5.

$$
\begin{gathered}
\overline{\overline{X i}}=\frac{\sum_{i=1}^{k} \overline{X i}}{n} \\
\overline{\overline{Y i}}=\frac{\sum_{i=1}^{k} \overline{Y i}}{n}
\end{gathered}
$$

Nilai ini memotong tegak lurus pada sumbu horisontal, yakni sumbu yang mencerminkan kinerja atribut $(X)$, sedangkan nilai memotong tegak lurus pada sumbu vertikal, yakni sumbu yang mencerminkan kepentingan atribut $(Y)$. Setelah diperoleh bobot kinerja dan kepentingan atribut, kemudian nilai-nilai tersebut diplotkan ke dalam diagram kartesius, seperti pada Gambar 2.

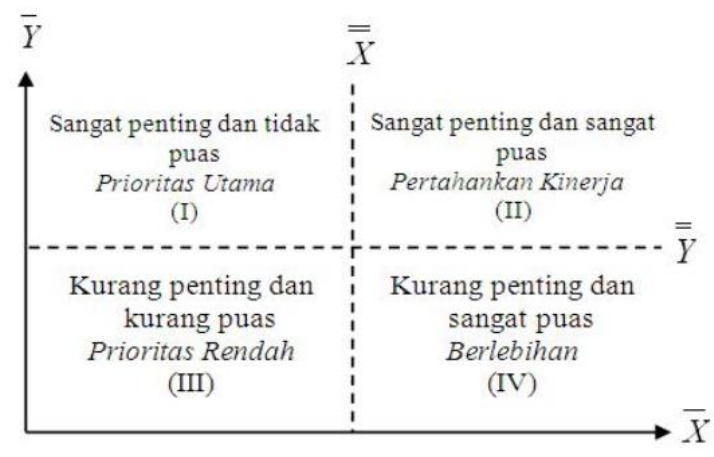

Gambar 2. Kuadran IPA 
Berikut penjelasan untuk masing-masing kuadran [15]:

1. Kuadran pertama : "Priorities for Improvement" atribut yang terletak pada kuadran ini merupakan atribut yang memiliki tingkat kinerja rendah namun tingkat kepentingannya tinggi. Sehingga sangat diprioritaskan untuk memperbaiki kualitas atribut yang terletak pada kuadran pertama. Salah satu caranya dengan meningkatkan kinerja atribut.

2. Kuadran kedua : "keep ip the good work" atribut yang terletak pada kuadran ini merupakan atribut yang memiliki tingkat kinerja tinggi dan tingkat kepentingan yang tinggi pula sehingga tidak diperlukan perbaikan kualitas yang perlu dilakukan hanya mempertahankan kualitas.

3. Kuadran ketiga : "low priority" atribut yang terletak pada kuadran ini merupakan atribut yang memiliki tingkat kinerja rendah namun tingkat kepentingan juga rendah sehingga tidak diprioritaskan untuk dilakukan perbaikan atau peningkatan kualitas

4. Kudran keempat : "Possible Overkill" atribut yang terletak pada kuadran terakhir ini merupakan atribut yang memiliki tingkat kinerja yang tinggi namun tingkat kepentingannya rendah sehingga kualitas pada atribut ini cenderung berlebihan dan disarankan untuk mengalokasikan tingkat kinerja pada atribut di kuadran satu.

\section{Hasil Penelitian dan Pembahasan}

Penerapan dari perkembangan teknologi telah dihadirkan oleh Perpustakaan Universitas Muhammadiyah Malang dengan adanya website pada Digital Library Universitas Muhammadiyah malang salah satu fasilitas yang di miliki perpustakaan berupa koleksi digital dengan adanya website ini diharapkan dapat membantu mahasiswa serta warga Universitas Muhammadiyah Malang. Dalam penelitian ini, menggunakan parameter Information Quality, Interaction Quality, Usability sebagai variabel penelitian ini. penelitian ini diharapkan dapat memberikan informasi serta bukti yang empiris dari pengguna website Digital Library Universitas Muhammadiyah Malang apakah telah memenuhi indikator-indikator tertentu sehingga tingkat kualitas dari sistem tersebut mudah dipelajari, dipercayai, diandalkan dan mendorong pengguna untuk menggunakan sistem tersebut sebagai alat bantu untuk mencari informasi terkait koleksi digital didalam Digital Library Universitas Muhammadiyah malang. Dalam konteks ini yang dimaksud sistem adalah website Digital Library Universitas Muhammadiyah malang. Pengukuran dilakukan dengan membagikan kuisioner kepada 89 responden yang ada pada fakultas FKIP Muhammadiyah Malang.

\subsection{Uji Kelayakan Kuisioner}

Pada tahap analisis instrumen akan dilakukan beberapa tahapan yaitu Uji Validitas dan Uji Reliabilitas.

\subsubsection{Hasil Uji Validitas}

Uji validitas merupakan salah satu pengujian pada kuisioner untuk mengetahui valid atau tidak nya suatu kuisioner yang digunakan dalam sebuah penelitian. Pada penelitian ini yang dilakukan untuk menguji validitas adalah mengujinya pada 30 orang dengan hasil pada Tabel 1 .

Tabel 1. Hasil Uji Validitas

\begin{tabular}{cccc}
\hline Atribut & $\mathrm{r}_{\mathrm{xy}}$ & $\mathrm{r}_{\text {tabel }} 5 \%(30)$ & Keterangan \\
\hline us1 & 0,559 & 0,361 & Valid \\
us2 & 0,676 & 0,361 & Valid \\
us3 & 0,632 & 0,361 & Valid \\
us4 & 0,623 & 0,361 & Valid \\
us5 & 0,573 & 0,361 & Valid \\
us6 & 0,532 & 0,361 & Valid \\
us7 & 0,606 & 0,361 & Valid \\
us8 & 0,514 & 0,361 & Valid \\
iq1 & 0,669 & 0,361 & Valid \\
iq2 & 0,621 & 0,361 & Valid \\
iq3 & 0,547 & 0,361 & Valid \\
iq4 & 0,639 & 0,361 & Valid \\
iq5 & 0,741 & 0,361 & Valid \\
iq6 & 0.675 & 0,361 & Valid \\
iq7 & 0,477 & 0,361 & Valid \\
\hline
\end{tabular}

REPOSITOR, Vol. 2, No. 3, Maret 2020: 351-362 


\begin{tabular}{llll} 
si1 & 0,577 & 0,361 & Valid \\
si2 & 0,542 & 0,361 & Valid \\
si3 & 0,602 & 0,361 & Valid \\
si4 & 0,580 & 0,361 & Valid \\
si5 & 0,631 & 0,361 & Valid \\
si6 & 0,629 & 0,361 & Valid \\
si7 & 0,459 & 0,361 & Valid \\
\hline
\end{tabular}

Pada penelitian ini penelitian menggunakan taraf signifikan sebesar $5 \%$ dengan nilai $r$ tabel sebagai acuan adalah sebesar 0,361 . Dari hasil uji validitas yang dilakukan oleh peneliti dengan bantuan software SPSS hasil yang menunjukkan semua atribut didalam kuisioner semua valid.

\subsubsection{Hasil Uji Reliabilitas}

Pada tahap selanjutnya adalah melakukan uji reliabilitas. Uji ini berbeda dengan pengujian validitas. Pengujiaan ini dilakukan untuk mengetahui konsistensi alat ukur, apakah alat ukur yang digunakan dapat diandalkan dan tetap konsisten jika pengukuran tersebut dilakukan. Suatu instrumen dianggap reliabel apabila instrumen tersebut dapat dipercaya sebagai alat ukur dalam penelitian. Data yang didapatkan seperti hasil pada Tabel 2.

Tabel 2. Hasil uji Reliabilitas

\begin{tabular}{cc}
\hline \multicolumn{2}{c}{ Reliability Statistics } \\
\hline Cronbach's Alpha & $\mathrm{N}$ of Items \\
0,912 & 22 \\
\hline
\end{tabular}

Pada Tabel 2 diatas didapatkan hasil nilai Alpha sebesar 0,912. Nilai tersebut kemudian dibandingkan dengan $r$ tabel dengan $n=30$ dengan taraf signifikan $5 \%$, nilai $r$ tabel sebesar 0,361 . Maka disimpulkan dari uji reliabilitas diatas yang memiliki nilai lebih besar dari r tabel yang artinya instrumen sudah reliabel dan terpercaya sebagai alat ukur penelitian.

\subsection{Analisis Data}

Pada penelitian ini, proses analisis data akan digunakan metode Importance Performance Analysis pada kuisioner yang akan di bagi menjadi 3 tahapan yaitu analisis kesesuaian, analisis kesenjangan (gap), dan kuadran IPA.

\subsubsection{Analisis Kesesuaian}

Tahap pertama dalam melakukan Importance Performance Analysis adalah melakukan pengujian dengan analisi kesesuaian untuk melihat sejauh mana angka kesesuaian antara kinerja dan kepentingan. Dengan menggunakan rumus yang sudah dijelaskan pada gambar 2.1 pada bab sebelumnya maka hasilnya seperti pada Tabel 3.

Tabel 3. Hasil Analisis Kesesuaian

\begin{tabular}{cccc}
\hline Atribut & Tingkat Kinerja & Tingkat Kepentingan & Tingkat Kesesuaian (\%) \\
\hline us1 & 413 & 327 & 126,30 \\
us2 & 412 & 314 & 131,21 \\
us3 & 427 & 355 & 120,28 \\
us4 & 415 & 309 & 134,30 \\
us5 & 361 & 358 & 100,84 \\
us6 & 362 & 363 & 99,72 \\
us7 & 349 & 366 & 95,36 \\
us8 & 412 & 306 & 134,64 \\
iq1 & 419 & 309 & 135,60 \\
iq2 & 412 & 315 & 130,79 \\
iq3 & 357 & 330 & 108,18 \\
iq4 & 404 & 303 & 133,33 \\
iq5 & 406 & 308 & 131,82 \\
iq6 & 368 & 359 & 102,51 \\
iq7 & 401 & 307 & 130,51 \\
si1 & 400 & 304 & 131,58 \\
\hline
\end{tabular}




\begin{tabular}{cccc}
\hline si2 & 399 & 304 & 131,25 \\
si3 & 387 & 291 & 132,99 \\
si4 & 324 & 301 & 107,64 \\
si5 & 313 & 293 & 106,83 \\
si6 & 397 & 293 & 135,49 \\
si7 & 288 & 277 & 103,97 \\
\hline Total & 8426 & 6992 & 120,51 \\
\hline
\end{tabular}

Pada Tabel 3 diatas menampilkan hasil dari perbandingan skor keseluruhan kinerja dan skor keseluruhan kepentingan untuk mengetahui tingkat kesesuaian dari website Digital Library Universitas Muhammadiyah Malang. Dari data diatas didapatkan hasil bahwa tingkat kesesuaian website adalah $120,51 \%$ yang berarti bahwa tingkat kesesuaian website Digital Library Universitas Muhammadiyah Malang berada pada kategori tingkat kesesuaian pengguna $>100 \%$ berarti kualitas layanan yang diberikan telah melebihi apa yang dianggap penting oleh pengguna.

\subsubsection{Analisis Kesenjangan}

Tahap kedua pada analisis data adalah analisis kesenjangan. Analisis ini digunakan untuk melihat sejauh tingkat kualitas dari website Digital Library Universitas Muhammadiyah Malang yang ditinjau dari nilai kesenjangan antara kualitas yang dirasakan (aktual) dan kualitas yang diinginkan atau harapan (ideal). Kualitas aktual ditunjukan melalui penilaian responden terhadap kinerja (performance) sedangkan unntuk kualitas ideal ditunjukan berdasarkan penilaian responden terhadap tingkat kepentingan (importance).

Untuk melakukan analisis kesenjangan menghitung skor rata-rata dari kinerja dan kepentingan pada setiap atribut. Untuk rumus yang digunakan sudah dijelaskan pada gambar 2.2. Dari hasil perhitungan nantinya akan dilihat hasilnya jika Qi atau GAP $>0$ maka hasilnya positif dengan kata lain kinerja sudah sesuai dengan kepentingan yang diharapkan oleh pengguna. Namun jika Qi atau GAP $<0$ berarti negatif dengan kata lain kinerja belum sesuai yang diharapkan oleh pengguna. Tabel 4 berikut merupakan hasil perhitungannya.

Tabel 4. Hasil Analisis Kesenjangan Variabel Usability

\begin{tabular}{cccc}
\hline Atribut & Rata-Rata Kinerja & Rata-Rata Kepentingan & Qi (GAP) \\
\hline us1 & 4,64 & 3,67 & 0,97 \\
us2 & 4,63 & 3,53 & 1,10 \\
us3 & 4,80 & 3,72 & 1,04 \\
us4 & 4,66 & 3,47 & 1,19 \\
us5 & 4,06 & 4,02 & 0,04 \\
us6 & 4,07 & 4,08 & $-0,01$ \\
us7 & 3,92 & 4,11 & $-0,09$ \\
us8 & 4,63 & 3,44 & 1,19 \\
\hline Rata-rata & 4,43 & 3,76 & 0,67 \\
\hline
\end{tabular}

Pada tabel kesenjangan variabel usability diatas terdapat beberapa atribut yang belum bernilai positif atau Qi (gap) < 0 yaitu atribut us6, us7 sedangkan untuk us1 us2, us3, us4, us 5 dan us8 sudah dikatakan positif karena Qi (gap) $>0$. Selanjutnya untuk total rata-rata keseluruhan kesenjangan pada variabel usability hanya 0,67 dalam hal ini berarti untuk variabel usability sudah sesuai yang diharapkan oleh pengguna.

Tabel 5. Hasil Analisis Kesenjangan Variabel Information Quality

\begin{tabular}{cccc}
\hline Atribut & Rata-Rata Kinerja & Rata-Rata Kepentingan & Qi (GAP) \\
\hline iq1 & 4,71 & 3,47 & 1,24 \\
iq2 & 4,63 & 3,54 & 1,09 \\
iq3 & 4,01 & 3,71 & 0,30 \\
iq4 & 4,54 & 3,40 & 1,14 \\
iq5 & 4,56 & 3,46 & 1,10 \\
iq6 & 4,13 & 4,03 & 0,10 \\
iq7 & 4,51 & 3,45 & 1,06 \\
\hline Rata-rata & 4,44 & 3,58 & 0,86 \\
\hline
\end{tabular}

REPOSITOR, Vol. 2, No. 3, Maret 2020: 351-362 
Pada Tabel 5 kesenjangan Information Quality diatas dijelaskan bahwa kualitas untuk setiap atribut sudah dikatakan positif dalam artian sudah memenuhi apa yang diharapkan oleh pengguna. Hasil yang didapatkan bahwa seluruh atribut pada variabel ini bernilai positif karena Qi (gap) > 0. Selanjutnya untuk total secara keseluruhan rata-rata pada variabel Information Quality memiliki kesenjangan positif yang bernilai 0,86 dan sudah memenuhi apa yang diharapkan pengguna.

Tabel 6. Hasil Analisis Kesenjangan Variabel Service Interaction

\begin{tabular}{cccc}
\hline Atribut & Rata-Rata Kinerja & Rata-Rata Kepentingan & Qi (GAP) \\
\hline Si1 & 4,49 & 3,42 & 1,07 \\
Si2 & 4,48 & 3,42 & 1,06 \\
Si3 & 4,35 & 3,27 & 1,08 \\
Si4 & 3,64 & 3,38 & 0,26 \\
Si5 & 3,52 & 3,29 & 0,23 \\
Si6 & 4,46 & 3,29 & 1,17 \\
Si7 & 3,24 & 3,11 & 0,13 \\
\hline Rata-rata & 4,03 & 3,31 & 0,71 \\
\hline
\end{tabular}

Pada Tabel 6 kesenjangan variabel Service Interaction diatas didapatkan hasil bahwa untuk seluruh atribut sudah sesuai yang diharapkan pengguna. Untuk keseluruhan penilaian terhadap variabel Service Interaction memiliki kesenjangan positif yang bernilai 0,71 dikatakan positif dan memenuhi apa yang diharapkan pengguna karena Qi (gap) $>0$.

Tabel 7. Hasil Analisis Kesenjangan Seluruh Variabel

\begin{tabular}{cccc}
\hline Atribut & Rata-Rata Kinerja & Rata-Rata Kepentingan & Qi (GAP) \\
\hline Usability & 4,43 & 3,76 & 0,67 \\
$\begin{array}{c}\text { Information } \\
\text { quality }\end{array}$ & 4,44 & 3,58 & 0,86 \\
$\begin{array}{c}\text { Service } \\
\text { interaction }\end{array}$ & 4,03 & 3,31 & 0,71 \\
\hline Rata-rata & 4,30 & 3,56 & 0,74 \\
\hline
\end{tabular}

Pada Tabel 7 kesenjangan pada keseluruhan variabel diatas dihasilkan bahwa untuk semua variabel sudah bernilai positif dan sudah memenuhi harapan pengguna. Pada variabel Usability memiliki kesenjangan yaitu 0,67 sedangkan untuk variabel Information Quality memiliki kesenjangan yang paling tinggi yaitu 0,86 . Hasil dari keseluruhan variabel yang didapatkan 0,74 dan untuk penilaian seluruh variabel dikatakan sudah memenuhi apa yang diharapkan oleh pengguna.

\subsubsection{Hasil Analisis Kuadran IPA}

Gambar 6 berikut merupakan tahap terakhir dalam penelitian ini, yaitu kuadran IPA. Analisis IPA digunakan sebagai metode analisa untuk membandingkan sampai sejauh mana antara tingkat kepentingan (importance) yang diukur dari harapan pengguna layanan dengan tingkat kinerja yang diukur dari kenyataan pelaksanaan yang dirasakan pengguna (performance). 1. Kuadran 1

Nilai pada kuadran ini memiliki kepentingan yang tinggi namun memiliki tingkat kinerja yang kurang. Artinya pada kuadran ini dibutuhkan perhatian untuk dilakukan perbaikan dan peningkatan dari atribut yang dianggap kurang. Layanan pada kuadran ini menjadi prioritas utama unntuk ditingkatkan kualiasnya. Dari hasil penelitian didapatkan bahwa ada 12 atribut yang termasuk didalam kuadran 1 yang perlu menjadi prioritas perbaikan yaitu atribut nomor 2 (jelas dan mudah dipahami), nomor 4 (mudah digunakan), nomor 8 (menciptakan pengalam positif), nomor 9 (informasi yang akurat), nomor 10 (informasi yang dapat dipercaya), nomor 12 (informasi yang relevan), nomor 13 (kemudahan dalam memahami informasi), nomor 15 (informasi format yang tepat), nomor 16 (reputasi yang baik), nomor 17 (aman melakukan interaksi), nomor 18 (informasi pribadi yang aman), nomor 21 (kemudahan berkomunikasi).

2. Kuadran 3

Pada kuadran ini atribut yang terletak merupakan atribut yang memiliki tingkat kinerja tinggi dan tingkat kepentingan yang tinggi pula sehingga tidak diperlukan perbaikan kualitas 
yang perlu dilakukan hanya mempertahankan kualitas. Dari hasil penelitian didapatkan ada 2 atribut yang terletak pada kuadran ini yaitu atribut nomor 1 (mudah mempelajari) dan nomor 3 (navigasi yang mudah).

3. Kuadran 3

Atribut yang terletak pada kuadran ini merupakan atribut yang memiliki tingkat kinerja rendah dan tingkat kepentingan juga rendah sehingga perlu dilakukan perbaikan atau peningkatan kualitas. Adapun 3 atribut yang terletak pada kuadran ini yaitu atribut nomor 19 (memberikan ruang personalisasi), nomor 20 (memberikan ruang komunitas), dan nomor 22 (yakin jasa sebagaimana dijanjikan).

4. Kuadran 4

Atribut yang terletak pada kuadran terakhir ini merupakan atribut yang memiliki tingkat kinerja yang tinggi namun tingkat kepentingannya rendah sehingga kualitas pada atribut ini cenderung berlebihan dan disarankan untuk mengalokasikan tingkat kinerja pada atribut di kuadran satu. Jadi pada kuadran ini ada yang dapat dialokasikan kekuadran 1 atau dihapus. Dari hasil penelitian didapatkan bahwa ada 5 atribut yang terdapat dikuadran ini yaitu atribut nomor 5 (tampilan yang menarik), nomor 6 (seperti website sejenis), nomor 7 (dapat diakses setiap saat), nomor 11 (informasi yang up to date), (informasi yang tepat).

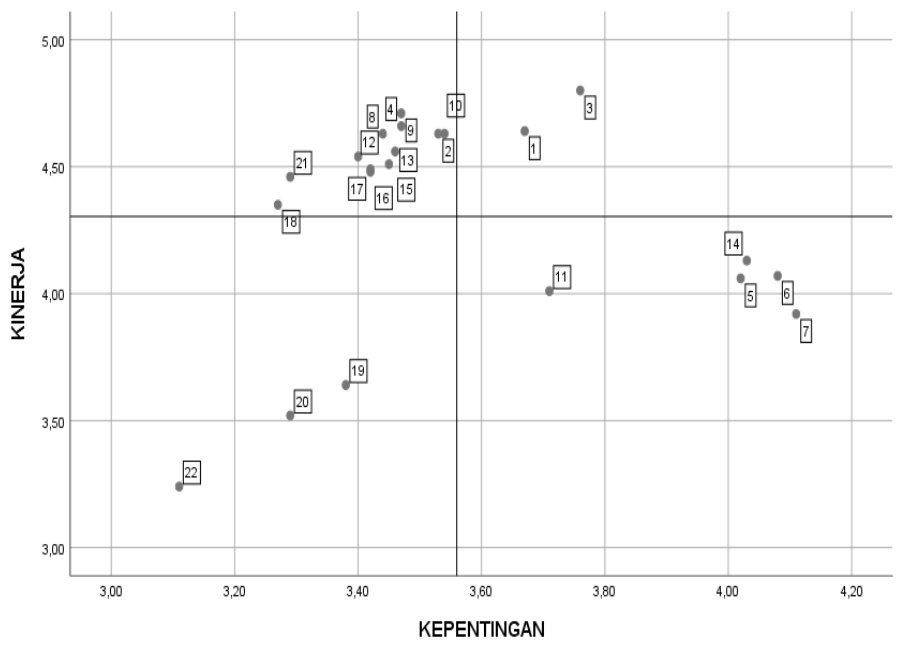

Gambar 3. Hasil Analisis Kuadran IPA

\subsection{Rekomendasi Perbaikan}

Pada tahap ini akan diberikan rekomendasi berupa mockup sederhana atau desain untuk menggambarkan apa saja yang perlu dilakukan perbaikan, serta saran-saran untuk meningkatkan kualitas.

1. Rekomendasi pertama merujuk pada atribut nomor 2 (us1), nomor 4 (us4) dan nomor 8 (us8) seperti halnya pada Gambar 4 pengelola web perlu mendesain agar mudah dipahami, mudah digunakan dan memberikan pengalaman yang positif.

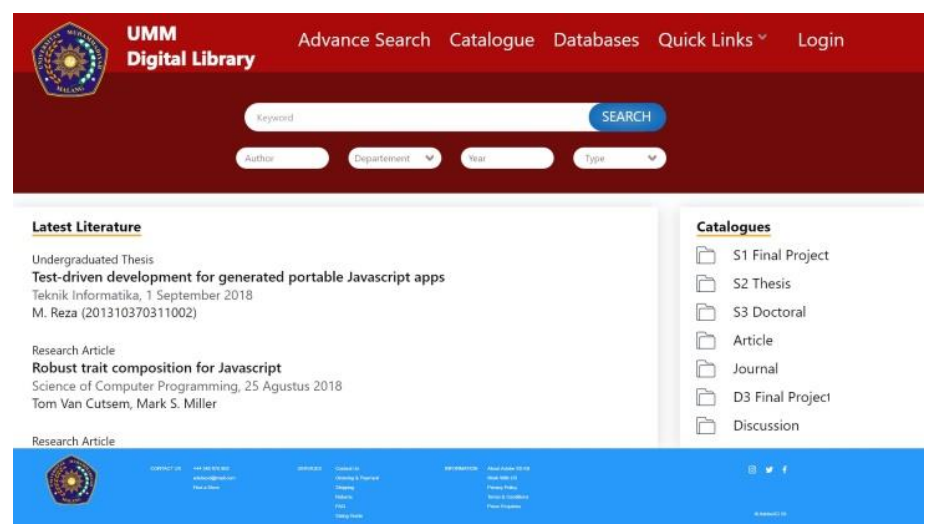

Gambar 4. Rekomendasi 1

REPOSITOR, Vol. 2, No. 3, Maret 2020: 351-362 
2. Rekomendasi selanjutnya merujuk pada atribut nomor 9 (iq1), nomor 10 (iq2), nomor 12 (iq4), nomor 13 (iq5), dan nomor 15 (iq7). Pada Gambar 5, atribut ini perlu perbaikan dari kualitas informasi yang akurat, dapat dipercaya, relevan, kemudahan memahami informasi.

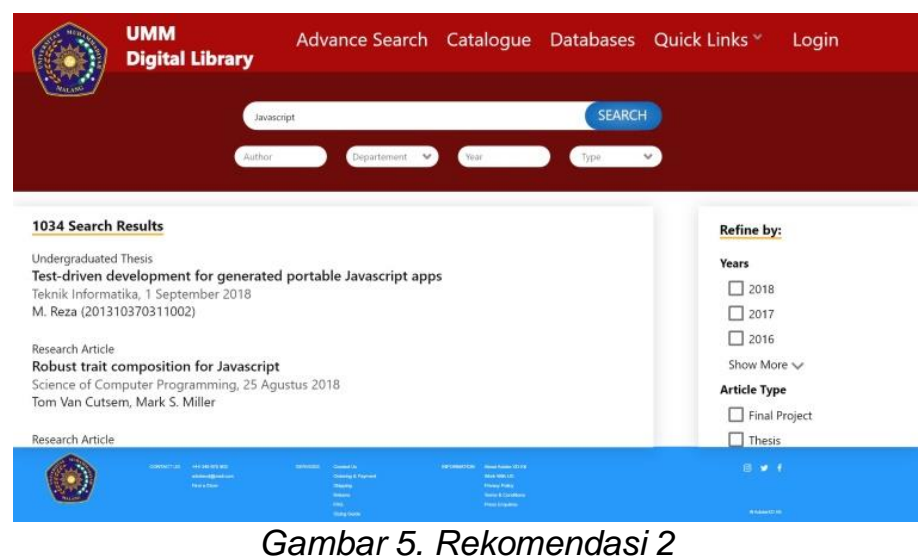

3. Rekomendasi selanjutnya pada Gambar 6 adalah menghilangkan atau merubah tampilan login pengguna karena pada sistem ini tidak berfungsi sama sekali dikarenakan hal ini hanya tertuju pada admin.

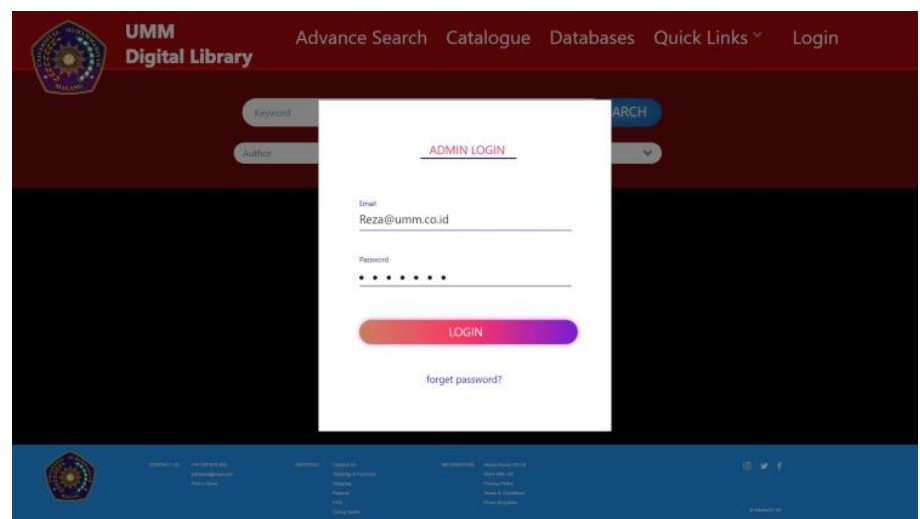

Gambar 6. Rekomendasi 3

4. Rekomendasi pada Gambar 7, selanjutnya merujuk dari atribut nomor 15 (si1) yaitu dengan format yang tepat. Sebagai contoh saat kita membuka salah satu artikel terlalu banyak abstrak yang dibaca oleh pengguna serta susunan bab pada srtikel tersebut terlalu jauh dibawah dan membuat pengguna harus menggeser kursor ke bawah agar ketemu bab-bab yang di cari dalam artikel tersebut.
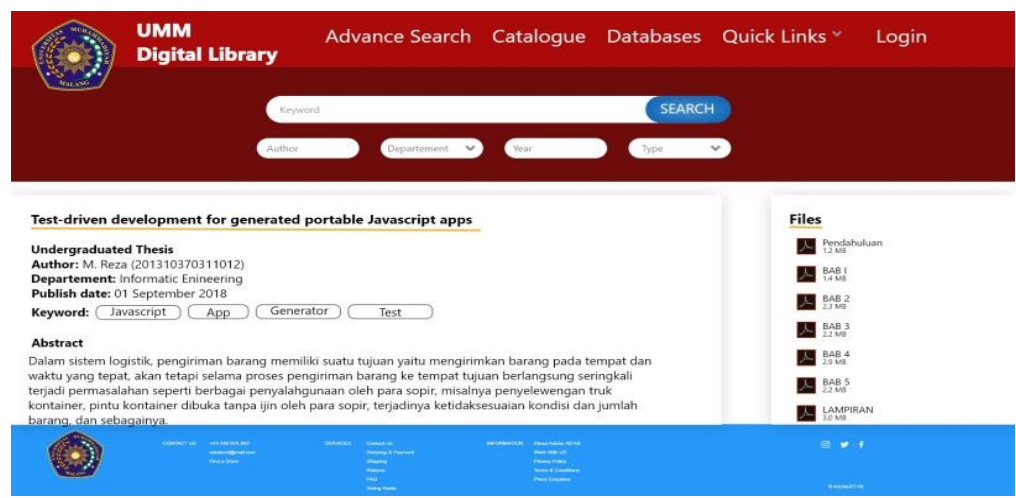

Gambar 7. Rekomendasi 4 
5. Selanjutnya untuk rekomendasi pada atribut nomor 16 (si1) disarankan untuk mengembangkan sistem dari digital library agar mendapat reputasi yang lebih baik.

6. Rekomendasi pada atribut nomor 17 (si2), nomor 18 (si3), dan nomor 21 (si6) disarankan memberikan ruang personialisasi agar pengguna merasa nyaman dan aman dalam menggunakan sistem ini.

7. Rekomendasi selanjutnya pada atribut nomor 19 (si4), nomor 20 (si5), dan nomor 22 (si7) sama dengan halnya dengan rekomendasi sebelumnya perlu diadakan ruang personialisasi dan ruang untuk komunitas agar meningkatkan kualitasnya.

\section{Kesimpulan}

1. Tingkat kesesuaian dari layanan website Digital Library Muhammadiyah Malang adalah $120,51 \%$ yang berarti berada pada kategori tingkat kesesuaian pengguna $>100 \%$ berarti kualitas layanan yang diberikan telah melebihi apa yang dianggap penting oleh pengguna. Namun yang menjadi pertimbangan lain adalah hasil dari perhitungan kuadran IPA. Menurut hasil kuadran IPA ada beberapa atribut yang perlu dilakukan perbaikan guna meningkatkan kualitas layanan.

2. Pada tahap analisis kesenjangan (gap) ditemukan bahwa pada variabel usability dengan nilai 0,67 , information quality 0,86 , service interaction 0,71 dan untuk rata-rata dari keseluruhan variabel 0,74. Dari hasil analisis kesenjangan ditemukan bahwa bernilai positif atau Qi (gap) > 0 yang artinya kinerja sudah sesuai yang diharapkan oleh pengguna.

\section{Referensi}

[1] N. Q. Nada and S. Wibowo, "Pengukuran Kualitas Layanan Sistem Informasi Akademik Menggunakan Metode Webqual 4.0," J. Inform. UPGRIS, vol. 1, no. 2, pp. 112-119, 2015.

[2] Republik Indonesia, Undang-Undang Republik Indonesia Nomor 43 Tahun 2007 Tentang Perpustakaan. 2007.

[3] A. R. Saleh, "Pengembangan Perpustakaan Digital Mendukung," no. 2005, 2011, pp. 1-8.

[4] G. Amanda Dwi P and F. Insan M.R, "Pengukuran Kualitas untuk Aplikasi Permainan pada Perangkat Bergerak berdasarkan ISO 9126," vol. V, no. 2, pp. 83-90, 2014.

[5] A. R. Wulan, "Pengertian dan esensi konsep evaluasi, asesmen, tes, dan pengukuran," pp. $1-12,2007$.

[6] X. Papadomichelaki, "Electronic Government," vol. 5693, no. May, 2009.

[7] a Parasuraman, V. a Zeithaml, and L. L. Berry, "SERQUAL: A Multiple-Item scale for Measuring Consumer Perceptions of Service Quality," Journal of Retailing, vol. 64. p. 28, 1988.

[8] S. J. Barnes and R. T. Vidgen, "Assessing the quality of auction web sites," Proc. Hawaii Int. Conf. Syst. Sci., no. September 2015, p. 189, 2001.

[9] Syaifullah and dicky oksa Soemantri, "Pengukuran kualitas website menggunakan metode webqual 4.0," Rekayasa dan Manaj. Sist. Inf., vol. 2, no. 1, p. 1, 2016.

[10] A. Al Baiti, Suprapto, and A. Rachmadi, "Pengukuran Kualitas Layanan Website Dinas Pendidikan Kota Malang Dengan Menggunakan Metode Webqual 4 . 0 dan IPA," J. Pengemb. Teknol. Inf. dan Ilmu Komput., vol. 1, no. 9, pp. 885-892, 2017.

[11] Sugiyono, Metode Penelitian Pendidikan Pendekatan Kuantitatif, Kualitatif, dan R\&D. Alfabeta, 2017.

[12] Syamsudin and Damiyanti, Metode Penelitian Pendidikan Bahasa. Bandung: PT. Remaja Rosdakarya, 2011.

[13] S. Azwar, Reliabilitas Dan Validitas, 4th ed. Yogyakarta: Pustaka Pelajar, 2012.

[14] B. S. Santoso, M. F. Anwar, and S. Hermawati, "Analisis Kualitas Website Menggunakan Metode WebQual dan Importance-Performance Analysis (IPA) Pada Situs Kaskus," no. September, 2015.

[15] J. A. Martilla and J. C. James, "Importance-Performance Analysis," J. Mark., vol. 41, no. 1, p. 77, Jan. 1977. 